\title{
Freelancer's E-Marketplace Information System Using Profile Matching Method
}

\author{
Riscal Arifin ${ }^{1}$, Benny Daniawan ${ }^{2}$, Dellih Wijaya ${ }^{3}$ \\ 1,2,3 Buddhi Dharma University, Information System, Banten, Indonesia
}

\begin{tabular}{l}
\hline SUBMISSION TRACK \\
\hline Received 20 December 2018; \\
Revised 12 January 2019; \\
Accepted 10 February 2019; \\
Available online 20 February 2019 \\
KEYWORD \\
\hline e-marketplace, Profile Matching, RAD, \\
Freelancer's. \\
CORRESPONDENCE \\
\hline
\end{tabular}

E-mail:

b3n2y.miracle@gmail.com

\section{INTRODUCTION}

In the current era the development of information technology and the internet is very high and increasingly widespread. With the technology that is connected without a time and place limit, so that both are widely applied in
A B S T R A C T

Now development of information technology and internet is very high and increasingly widespread. With the technology which is connected without limits time and place. The development of online transactions is very much in demand compared to conventional transactions, without a medium to make the right transactions, it will hamper the efficiency and effectivenes, so that transaction activities between sellers and buyers become inhibited. Therefore we need a solution to solve these problems, the progress of e-commerce in Indonesia is needed for the community. Developing technology can be implemented into the business field. So an e-marketplace application is needed to be built and designedas a web to transact between sellers and buyers. This website is developed using the profile-matching method and with the design of RAD (Rapid Application Development) which is an object-oriented approach to the system with the main goal of shortening the application processing time and process so that as soon as possible empowering the software system precisely and quickly which consists of the requirements planning, design system, instruction and implementation. The e-marketplace information system can increase freelancer revenue and the level of customer convenience in finding workers according to what is needed and can make the transaction process efficient and effective. As a result, it helps to provide decision criteria for the client selection. business. E-commerce is a transaction using the internet and computer with a web browser to introduce, offer, buy and sell products [1]. This e-commerce is a part of

e-business that covers a wider area. As looking through the benefits of technological advances, 
there are many people who have started to develop their systems through a website where humans can get the information needed just by accessing it through websites that are connected to the internet. Along with the rapid development of technology many websites are made to facilitate transactions for both parties, but do not pay attention to aspects of the transaction process that pays attention if it is positioned as a customer by the Rapid Application Development (RAD) method which is part of the System Development Life Cycle or SDLC, SDLC is a method which software can be systematically developed and that will increase the likelihood of completing a project software within the time limit and maintain the quality of software products according to the standard [2]. RAD is the development of an information system with a relatively short time. To develop a normal information system requires a minimum of 180 days. But with the RAD method a system can be completed in only 60-90 days [3]. With the Profile-Matching method it will be easier for customers to search and find according to what is needed, especially for services where the freelancers do the work in accordance with what is desired by the customer or client whocreates work for the freelancers and the information provided must be clear and precise in order to avoid mistakes in project work.

\section{STUDY OVERVIEW}

The study overview used as a reference for the study consisted of four journals.

The first journal discussed the research of using the RAD method to make the system process faster and create systems according to the needs in order to facilitate customers in using the website system that is made and make changes if there must be a change in the menu given in 2018 to get results namely the system becomes more effective to make the fast transaction process [4].

The second journal reviewing the research on the prototype UI that became part of the needs for customers where getting results is the customer becomes easier in conducting transaction processes that support customers to gain new experiences when using a website [5]. The third journal discussedthe research in terms of e-marketplaces where in this journal reviews how to be able to design a website to be used in accordance with the needs that get results namely the system can be used in accordance with customer needs or in making transactions and can re-do transactions [6] .

The fourth journal used to be a benchmark for measuring values in the use of the profile matching method for ranking in the system that can facilitate customers to find workers who fit the desired criteria from the results of the journal obtained profile matching method has an accuracy level of $98.8 \%$ of manual counts and results in the website system [7]. 


\section{FRAMEWORK}

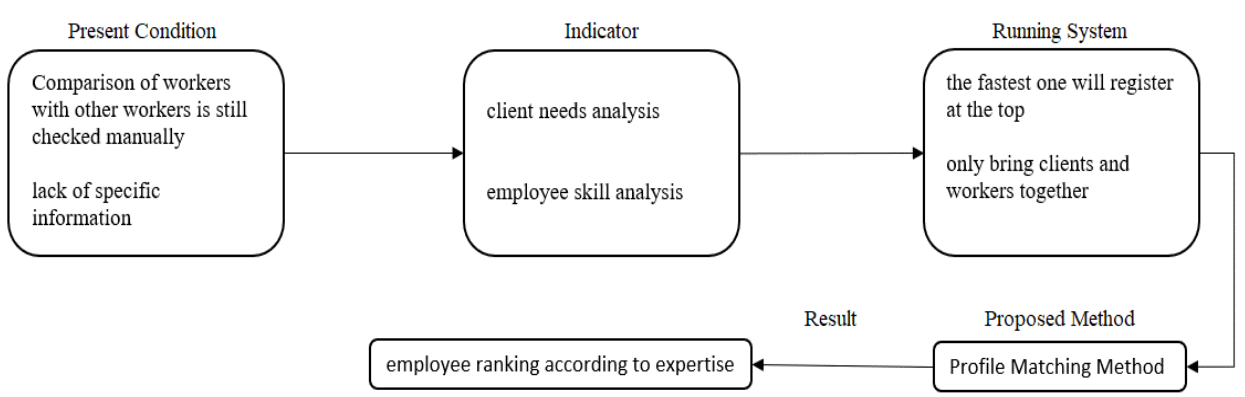

Figure1 :Framework

\section{METHOD}

\section{Profile Matching}

Profile Matching or with Competency GAP Analysis is a decision making mechanism by assuming that there is an ideal level of predictor variables that must be possessed by applicants, rather than the minimum level, that must be passed. In profilematching, good and bad groups of employees are identified. Employees in the group were measured using several assessment requirements. Aspects of decision support assesment system is designed, so that users who in this case are managers of human resources can dynamically determine aspects of their own assessment and that make decision support system can be used more widely [8] [9]. These competencies / abilities must be fulfilled by custom service owners. In the Profile Matching process outline is the process of comparing individual competencies into standard competencies, the differences in competencies can be known (also called GAP), the smaller the GAP result is, then the smaller the value is as well, which means there would be a higher probability.

The GAP calculation formula as follows:

GAP = Individual Competencies - Standard

Notes : Competencies

$\begin{array}{ll}\text { GAP } & \text { : Competence Difference } \\ \text { Individual Competency } & : \text { Individual Competency } \\ & \text { Value } \\ \text { Standard Competency } & : \text { Standard Competency }\end{array}$

\section{Value}

After determining the weight of the GAP value. Then each aspect is grouped into 2 (two) groups, namely the Core Factor and Secondary Factor groups. For the calculation of core factors can be shown as follow:

\section{$\mathbf{N C F}=\underline{\Sigma} \mathbf{N C}$ \\ $\Sigma$ IC}

Notes :

NCF : The average value of the Core Factor

NC : Total number of core factor values

IC : Number of core factor items

Whereas the secondary factor calculation can be shown in the formula below :

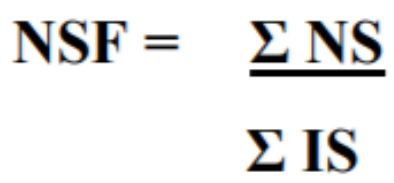

Notes :

NSF : The average value of the Secondary Factor

NS : The total number of secondary factor values

IS : Number of secondary factor items

From the calculation results of each of the aspects above then the total value is calculated based on the presentation of the core and secondary. Examples of calculations can be seen as follow:

$N=(x) \% N C F+(x) \% N S F$ 
Information :

$$
N \text { : Total value of aspects }
$$

$N C F \quad$ : The average value of the core factor

$N S F \quad$ : The average value of the secondary factor

$(x) \% \quad$ : Percent value entered

The end result of this process is the ranking of the choices of custom service owners. Determination of ranking refers to the results of certain calculations. The calculation can be shown as follow:

$H a=(x) \% N 1+(x) \% N 2+(x) \% N 3$

Information :

$\mathrm{Ha}$ : The final result

N1 : Criteria Value 1

N2 : Criteria Value 2

N3 : Criteria Value 3

$(x) \%$ : Percent Value inputted

\section{DISCUSSION}

Profile Matching Step :

a. There are 5 criteria: Web Develop, Photo \& Videography, Make Up Artist, Editor, and Graphic Design.

b. Look for GAP values, which have 3 levels that have different weights, that is expert, intermediate, and beginner.

c. Determine weights based on GAP

Table 1. Rating Weight

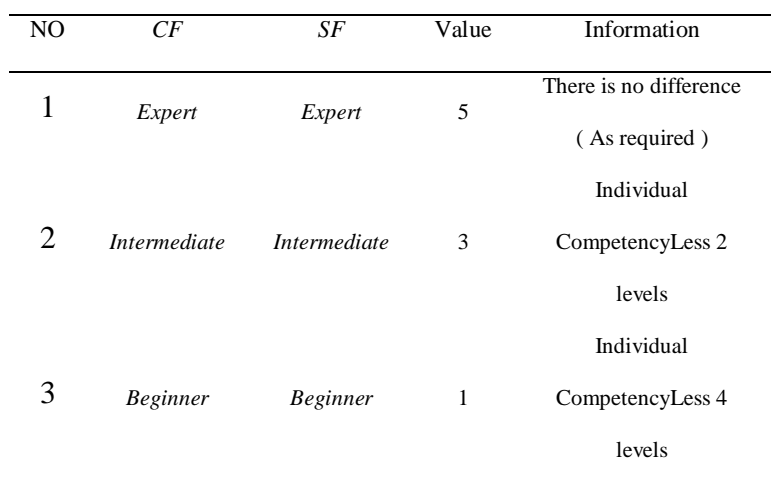

Table 2. Example of Expertise

\begin{tabular}{ccccccccc}
\hline No & Name & CF 1 & CF 2 & SF 1 & SF 2 & SF 3 & SF 4 & SF 5 \\
\hline 1 & Edo & E & I & E & B & E & I & E \\
2 & Adi & I & E & B & I & I & E & E \\
3 & Ley & E & - & B & I & - & B & B \\
4 & Chen & E & E & E & E & I & E & E \\
\hline
\end{tabular}

Table 3. Giving Value

\begin{tabular}{lcccccccc}
\hline No & Name & CF1 & CF2 & SF 1 & SF 2 & SF 3 & SF 4 & SF 5 \\
\hline 1 & Edo & 5 & 3 & 5 & 1 & 5 & 3 & 5 \\
2 & Adi & 3 & 5 & 1 & 3 & 3 & 5 & 5 \\
3 & Ley & 5 & 0 & 1 & 3 & 0 & 1 & 1 \\
4 & Chen & 5 & 5 & 5 & 5 & 3 & 5 & 5 \\
\hline
\end{tabular}

e. Calculate NSF and NCF

Table 4. Calculation core/secondary

factor

\begin{tabular}{|c|c|c|c|c|}
\hline No & Name & $\begin{array}{c}\mathrm{NCF}=\underline{\Sigma \mathrm{NC}} \\
\Sigma \mathrm{IC}\end{array}$ & $\begin{array}{c}\mathrm{NSF}=\underline{\Sigma \mathrm{NS}} \\
\Sigma \mathrm{IS}\end{array}$ & $\begin{array}{c}\mathrm{N}=\text { NCFx } 60 \%+ \\
\text { NSFx } 40 \%\end{array}$ \\
\hline
\end{tabular}

$\begin{array}{lllll}1 & \text { Edo } & 4 & 3,8 & 3,92\end{array}$

$\begin{array}{lllll}2 & \text { Adi } & 4 & 3,4 & 3,76\end{array}$

3 Ley $2,5 \quad 1,2 \quad 1,98$

$\begin{array}{lllll}4 & \text { Chen } & 5 & 4,6 & 4,84\end{array}$

f. Calculating the Total Value

The final result is the ranking of freelancers. Determination of ranking refers to the results of calculations as follows: 
$\mathrm{Ha}=(\mathrm{x}) \% \mathrm{x}$ Ncategory

$\mathrm{Ha} \quad=$ Final Results

Ncategory $=$ Values from categories

$(\mathrm{x}) \%=$ The percent value inputted

g. Perform Ranking Process

Table 5. Final Value Calculation

\begin{tabular}{ccc}
\hline No & Name & Final Result \\
\hline 1 & Chen & 484 \\
2 & Edo & 392 \\
3 & & \\
& Adi & 376 \\
4 & & \\
& & \\
& & \\
\hline
\end{tabular}

\begin{tabular}{llc}
\hline Name & Status & Score \\
\hline chen & Applytoclient: & 484 \\
\hline Edo & Applytoclient & 392 \\
\hline Adi & Applytoclient & 376 \\
\hline Ley & Applytoclient: & 198 \\
\hline
\end{tabular}

Figure2 :Ranking on the system

According to the expertise possessed it can be concluded that the top ranking is the candidate with the highest score in accordance with the calculation of the expertise he has.

\section{DISCUSSION}

Tests conducted in this study are Black Box testing to determine the level of success of the system, Black Box Robustness Testing is used to prove that there are no errors if the input data is invalid.

\section{Black Box Testing}

Black Box Testing is a testing software in terms of functional specifications without testing the design and program code [10].

With this type of Robustness Testing, the testing is carried out with the data input process such as features provided whether it is suitable or not and whether an error occurs or not during the input process.

Robustness Testing is a testing with input data selected outside the specifications that have been defined. The purpose of this test is to prove that there are no errors if the input is invalid [11].

The following Black Box testing displays a menu in the following table :

\section{Table 6. Black Box Testing}

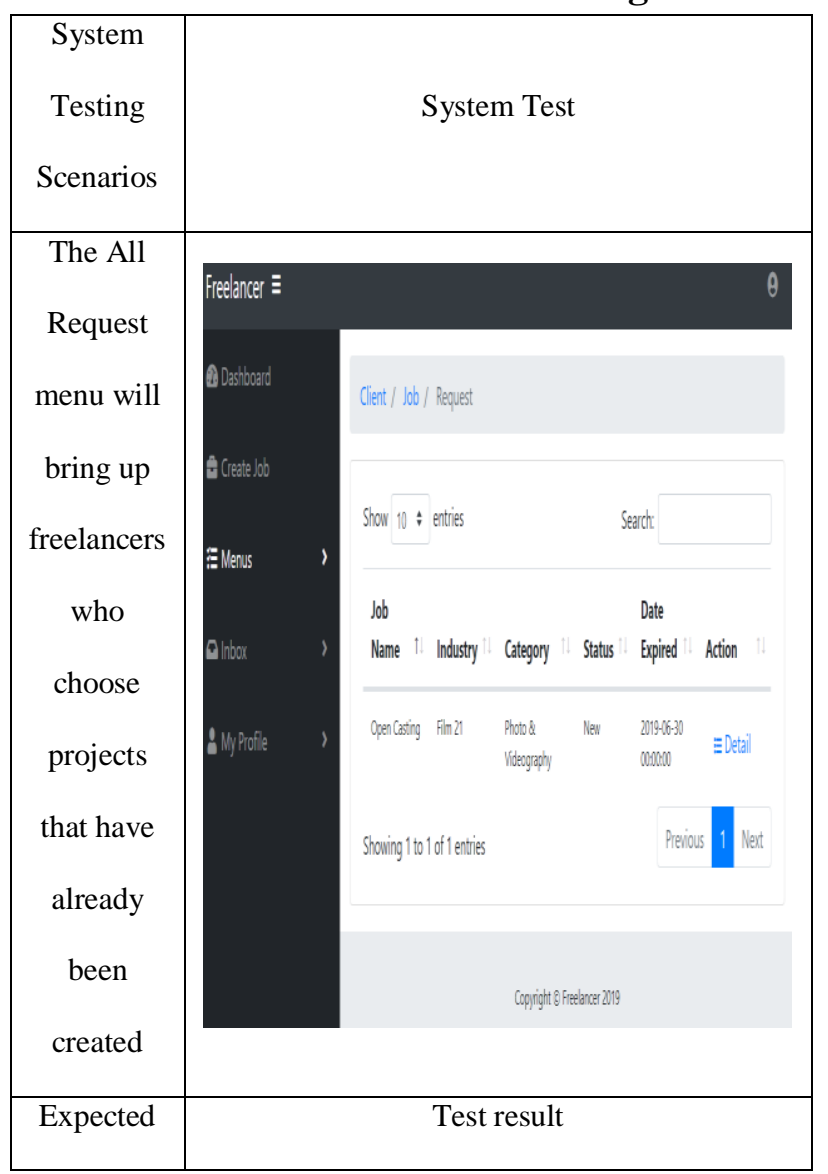




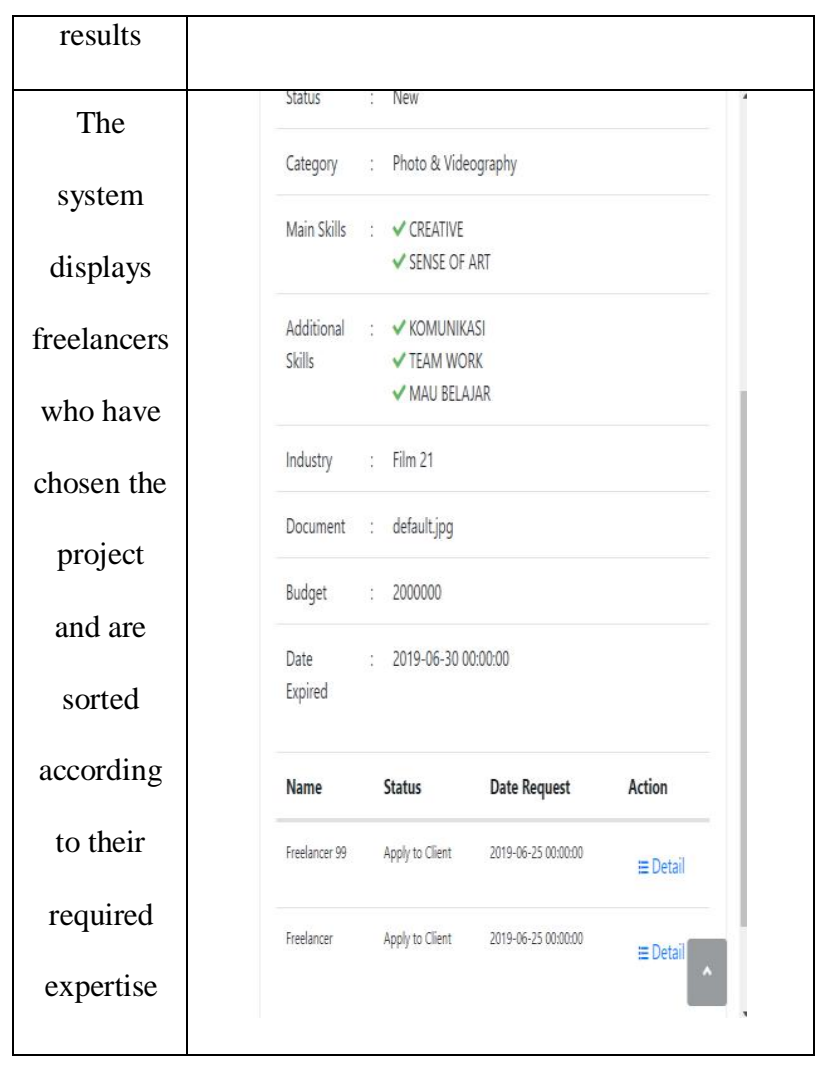

From the nine tests conducted on the menus in the system design:the Login Menu, Client Main Menu, Freelancer Main Menu, Create Job Menu, Job Search Menu, All Request Menu, Task List Menu, and Topup Menu. By using black box testing it is concluded that each module and menu has the results as expected.

\section{CONCLUSION}

From the results of the analysis and design it can be concluded that :

a. Client decision support system with the Profile Matching method helps the clients in making decisions with a ranking system of scores obtained by freelancers.

b. The system provides detailed information about the work created by the client as well as the expertise possessed by the freelancer.

c. The system can provide options according to the needs that is needed by the client.

\section{REFERENCES}

[1] S. Isyanahapsari, dan S. Nurseto, "Pengaruh Periklanan Dan Kualitas Pelayanan Terhadap Keputusan Pembelian Secara Online Pada Situs Belanja Online (Studi Kasus pada Pengguna E-commerce Elevenia Di Kota Semarang)", Jurnal Ilmu Administrasi Bisnis, Vol. 7, No. 1, pp. 117-129, 2018. 
[2] J. Andry, "Pengembangan Aplikasi Backup dan Restore Secara Automatisasi Menggunakan SDLC Untuk Mencegah Bencana”, Jurnal Muara, Vol. 1, No. 1, pp. 29-38, April 2017

[3] S. Aswati, M. Ramadhan, A. Firmansyah, K. Anwar, "Studi Analisis Model Rapid Application Development Dalam Pengembangan Sistem Informasi", Jurnal Matrik, Vol. 16, No. 2, Mei 2017.

[4] S. Susilowati, dan M. Negara, "Implementasi Model Rapid Aplication Development (RAD) Dalam Perancangan Aplikasi E-Matkerplace”, Jurnal Techno Nusa Mandiri, Vol. 15, No. 1, pp. 25-30, Maret 2018.

[5] A. Prakasa, dan F. Ardiansyah, "Perancangan User Experience Aplikasi Marketplace Paket Wisata Indonesia untuk Wisatawan Lokal”, Jurnal Ilmu Komputer Agri-Informatika, Vol. 5, No. 1, pp 51-60, 2018.

[6] R. Marco, dan B. Ningrum, "Analisis Sistem Informasi E-Marketplace Pada Usaha Kecil Menengah (UKM) Kerajinan Bambu Dusun Brajan”. Jurnal Ilmiah DASI, Vol. 18, No. 2, pp 49-53, Juni 2017.

[7] A. Setiawan, D. Andreswari, dan F. Coestera, "Implementasi Metode Analisis GAP dan Profile Matching Untuk Seleksi Penerimaan Penyiar Radio (Studi Kasus PT. Radio Swaraunib FM)", Jurnal Rekursif, Vol. 5, No. 3, pp 249-259, November 2017.

[8] Kusrini, Sistem Pendukung Keputusan, Yogyakarta, 2007.

[9] A. Pataropura, R. Riki, and J. Manu, "Decision Support System for Selection of Assembly Using Profile Matching Method and Simple Additive Weighting Method (Case Study: GKIN Diaspora Church)", bt, vol. 2, no. 1, pp. 43-52, Oct. 2019.

[10] A.S Rosa, dan M. Shalahuddin, Rekayasa Perangkat Lunak Struktur dan Berorientasi Objek, Informatika, Bandung, 2014.

[11] A. Putra, R. Nyoto, dan H. Pratiwi, “ Rancang Bangun Aplikasi Marketplace Penyedia Jasa Les Private di Kota Pontianak Berbasis Web", Jurnal Sistem dan Teknologi Informasi, Vol. 5, No. 1, 2017.

\section{BIOGRAPHY}

Riscal Arifin, Graduated from the Information Systems Study Program (S1) in the Electronic Business concentration in 2019.

Benny Daniawan, Graduated from the Information Technology Study Program (S1) in 2011, continued his Masters in Information Systems in 2014 and graduated in 2016. He currently serves as a Lecturer in Information Systems Study Program, Buddhi Dharma University.

DellihWijaya, Graduated from the Information System Study Program (S1) in 2003, continued his Masters in Management in 2005 and graduated in 2009. She currently serves as a Lecturer in Information Systems Study Program, Buddhi Dharma University. 